Invest. Pens. Crit.(ISSN 1812-3864; eISSN 2644-4119)

Vol. 10, No. 1, Enero - Abril 2022. pp. 25 -31

DOI: https://doi.org/10.37387/ipc.v10i1.273

Artículo Científico

\title{
Aplicabilidad del BFI-S en Panamá
}

\section{BFI-S Applicability in Panama}

\author{
Ericka Matus ${ }^{1,}$, Lorena Matus², Ana Toriz ${ }^{3}$, y Jay Molino ${ }^{4}$
}

${ }^{1}$ Department of Biosciences and Public Health, Universidad Especializada de las Americas, Corregimiento de Ancón, Albrook, Paseo de la Iguana, Panamá, 0843-0141.

Sistema Nacional de Investigación, SNI, SENACYT, Panamá.

(Chttps://orcid.org/0000-0002-3184-982X

${ }^{2}$ Department of Psychology, Universidad Iberoamericana, Santa Fe, Mexico City, Mexico.

https://orcid.org/0000-0001-7259-1530

${ }^{3}$ School of Bussiness administration and Accounting, Universidad de Panamá, El Cangrejo, Simón Bolivar Street.

https://orcid.org/0000-0002-8013-6076

${ }^{4}$ Department of Biosciences and Public Health, Universidad Especializada de las Americas, Corregimiento de Ancón, Albrook, Paseo de la Iguana, Panamá, 0843-0141.

Sistema Nacional de Investigación, SNI, SENACYT, Panamá.

Chttps://orcid.org/0000-0001-5764-7874

* Autor por correspondencia: Jay Molino, jay.molino@udelas.ac.pa

Recibido: 24 de agosto de 2021

Aceptado: 14 de noviembre de 2021

\section{Resumen}

Se analizó las características psicométricas de la escala BFI-S de 5 elementos y se determinó la eficiencia de la escala para obtener las características psicométricas deseadas. El estudio es de campo no experimental, prospectivo y aplicativo, con un diseño ex post facto transversal y correlacional. La muestra fue no probabilistica de 648 adultos panameños que respondieron a la escala de personalidad BFI, como parte de un estudio internacional sobre el impacto psicológico y conductual de la crisis por COVID-19 llamado COVIDiSTRESS global survey de Lieberoth et al. El instrumento forma parte de un inventario que integra otras ocho escalas. Se empleó el método de extracción de componentes principales y el método de rotación utilizado fue el de normalización Varimax con Kariser. Los datos se analizaron con el estadístico Alpha de Cronbach, para calcular la confiabilidad de la prueba. Los resultados indican que el constructo no cuenta con validez ni confiabilidad para la muestra panameña.

Palabras clave: BFI-S, COVID-19, Panamá, pandemia, escala. 


\begin{abstract}
Analyzed the psychometric characteristics of five BFI-S scales and determined the efficiency of the scale to obtain the required psychometric characteristics. The study is a non-experimental, prospective, and applied field study with a cross-section and related post hoc design. This sample is a non-probabilistic sample of 648 Panamanian adults who responded to the BFI Personality Scale, part of an international study on the psychological and behavioral impact of the COVID-19 crisis called the COVIDiSTRESS Global Survey conducted by Lieberoth and others. The instrument is part of an inventory that integrates eight other scales. The principal component extraction method was used, and the rotation method used was the Varimax normalization with Kaiser. The data was analyzed with Cronbach's Alpha statistic to calculate the reliability of the test. The results indicate that the construct does not have validity or reliability for the Panamanian sample.
\end{abstract}

Keywords: BFI-S, COVID-19, Panama, pandemic, scale.

\title{
Introduction
}

The impact of the pandemic on individuals and society has changed people's life concepts. Similarly, the deterioration of health and education has deepened, and the effect of social disparities is more pronounced than ever.

One of the phenomena that have attracted psychological attention is that many people from various countries began to propose actions, interventions, and solutions in different areas throughout the pandemic. This completely conflicting self-imposed task requires research. It is essential to understand the character traits of those who leave their comfort zone and those waiting for others to resolve emergencies.

With this outlook, Sutin et al. Conducted a pre-test post-test investigation on the possible alterations that may be reflected in the changes in psychological function due to the COVID-19 situation. First, personality traits were measured with the Big Five Inventory-2 instrument with 60 items in a sample of 2,137 in the United States of America. The authors found that neuroticism decreased over the six weeks the study lasted, especially in the areas of anxiety and depression.

They also found through pre-testing that going to work when sick is considered the behavior of responsible and conscientious workers. In the post-test, the result was the opposite. The significance of taking ill to work has changed with the epidemic.

Although the theory suggests that personality traits will last a lifetime and are difficult to change, the author wants to prove this in a very unpleasant and stressful pandemic situation. Therefore, they concluded that the changes recorded in the sample were due to the response to the coronavirus outbreak, not due to personality changes (Sutin, Luchetti, Aschwanden, Lee, Sesker, Strickhouser, Stephan, \& Terracciano, 2020).

Brandt et al.'s research aimed to study personality traits from late childhood to late adulthood through the Big Five model. The authors report that the Short Big Five Inventory (BFI-S) has the psychometric structure to evaluate personality traits by age groups (Brandt, Becker, Tetzner, Brunner, Kuhl, \& Maaz, 2020). They worked with two samples in Germany. The first one of 1090 sixth grade children from 68 randomly selected primary schools in the Land of Brandenburg. The second sample was obtained from the Socioeconomic Panel in Germany. Households were chosen using a multi-stage random sampling strategy that included 18,789 adults.

The results show that the overall scale structure of the BFI-S five factors can be used from late childhood to late adulthood; that is, there is evidence that personality trait metrics are comparable (Brandt, Becker, Tetzner, Brunner, Kuhl \& Maaz, 2020).

In another study, Das and Arora (2020) reported that adjustments to unfortunate situations in life and ways to cope with or solve these problems could be explained by the personality components of the five significant factors related to resilience. The results show a significant positive correlation between resilience and consciousness, resilience and openness to experience, resilience to extraversion. However, resilience is inversely correlated with neuroticism. 
Stricker et al. (2019) carried out a meta-analysis on the relationship between multidimensional perfectionism and the five great personality traits, intending to reinforce the conceptual framework necessary to integrate the approaches and measures used in perfectionism research. They used 72 samples that included a total of 21,573 participants.

Schmidt et al. al (2010) wrote a paper on the history of the Eysenck personality psychobiological model. They described the conceptual process of the instrument, which can be traced back to pre-Socratic Greek thought, the stage of the analytical model, and the personality theory.

Mosques et al. (2019) conducted a survey in which they combined samples from Argentina, Spain, and the United States, used in two different languages, the Spanish version is used in Argentina. The other two languages use English instruments. They applied a five-factor personality model (FFM), emphasizing psychometric structure (validity and reliability).

According to Salgado et al. (2016), personality theory can be divided according to their viewpoints. For example, the approach focuses on (Allport, 1937; Cattell, 1943) characteristics and behavior patterns, about personality or motivation (Murray, 1938; Ryan \& Decy, 2000), recognition Knowledge (Mischel \& Shoda, 1995; Bandura, 2001), the influence of social and cultural background (Markus \& Kitayama, 1991; Nisbett, 2003) or those concerned with mechanisms and biological and evolutionary structures (Eysenck, 1985 Years; Zuckerman, 1991; De Young \& Gray, 2009).

Although there is a lot of research on the use and applicability of the BFI scale, Spanish is regional in Latin America, so it is necessary to consider lexical and semantic differences (Salgado, Vargas-Trujillo, Schmutzler \& Wills-Herrera, 2016). Therefore, when the scale was applied to the Colombian sample, the author found that the meaning of certain items was questionable. For example, 323 young undergraduates enrolled in a private university in Bogotá were between 17 and 25.

In 2018, Domínguez-Lara and Merino-Soto published work on two short versions of BFI application among 332 senior students in Peru to determine the psychometric properties of the sample. The results show that these tools have not gained validity or reliability. They believe this may be because the five-element model has not been thoroughly tested in China, and the tools developed in different cultures need to be evaluated for dimensionality. Although these are Spanish versions of Latin America, it is not enough to use and copy them.

\section{Methods}

\section{Study design}

Facto, cross-sectional and descriptive Expoxt design, non-experimental, prospective, applicative, and field.

\section{Participants}

As part of the international research on the psychological and behavioral impact of the COVID-19 crisis, Panama, like more than 150 countries, accepted the invitation to participate in the survey, the COVIDiSTRESS global survey by Lieberoth and others (2020).

The survey involved 765 Panamanian adults who responded electronically. The selection of samples is nonprobabilistic and snowballing. Data collection started on May 10 and ended on May 30.

A total of 648 people answered the BFI-S thoroughly; that is, 117 people did not fully answer the scale, so they are not considered in the analysis.

\section{Measurements}

A five-factor model (FFM) is used to measure a five-dimensional list of the Big Five personalities, which is currently widely accepted in Panama. The dimensions are extroversion, openness, neuroticism, kindness, and consciousness. They integrate 60 items into one version. As far as China is concerned, they use the Big Five Personality Scale (CBF-PI), a 134-item self-report scale (Zhang, Wang, He, Jie, and Deng, 2019). In addition, 
there is another Big Five Personality Trait Questionnaire (BFPTSQ) with 50 items and more than 44 items.

From these patterns, a short version was made, just like the Big Five Inventory-15, also known as BFI-S (Soto \& John, 2017), which uses three items in each dimension, In this way, there are a total of 15 questions, and there are five answer options on the Likert scale.

For this research, the version of the BFI-S with six response options was used, as shown in the appendix.

Because the inventory used is the same for all participating countries, each region needs to obtain the psychometric characteristics for its population.

\section{Procedure}

The study arises from the search for answers to the unexpected pandemic by Covid-19, in which a group promotes a global survey that includes nine different scales to know the psychological and behavioral impact of the population, inviting to join all countries named COVIDiSTRESS global survey by Lieberoth et al., (2020).

The author sent virtual calls to well-known psychologists in different professional fields through social networks to launch the participation movement of the Panamanian population. Carmen Fernández, Ana María Florez, Christian Tejeira, Aelén López, Hilda Avilés, Ibeth Vergara, Jéssica Chung, Ricardo Turner, Cristóbal Nieto, Nuria Araguás, Melba Stanziola, Librada Guerra, and Virginia Castillero helpe with the task of looking for participants and promoting the study. Since June, the data has been published on the COVIDiSTRESS global survey website and, a statistical analysis was carried out.

Considering the number of people who answered the instruments, the reliability assessment was carried out through the Cronbach's alpha statistic, and the construct validity was calculated using factor analysis.

\section{Statistical Analysis}

The data were analyzed through the statistical program for social sciences SPSS 24 @. The 648 cases. We were subjected to the factorial analysis inferential statistic to determine the scale's construct validity using the principal components extraction method and Kaiser's Varimax normalization rotation method. The data were subjected to Cronbach's Alpha analysis.

\section{Ethical considerations}

The research ensured that each participant accepted the informed consent on using and managing the information collected, which has all the ethical considerations required in Panama for studies of this nature.

\section{Results}

For the construct validity, the results obtained of the Big Five Inventory in its short version (Big Five Inventory-Short), in a Panamanian population, are five components that together have an explained variance of $60.657 \%$. They converged in seven iterations, performed with the principal component extraction method, and the rotation method used was the Varimax normalization with Kaiser.

The data were analyzed with Cronbach's Alpha statistic to calculate reliability, which yielded a value of .558 with the 15 items considered limited internal consistency.

The items that make up the conceptual factors, the factor load weights, the corrected total item correlation (rit), and the reliability of the elements as shown in table 1.

It is important to note that items $3,10,12,13$, and 15 (see appendix) reported factorial weights greater than .30 in at least two different factors, which could be part of the explanation for the limited validity.

Regarding Cronbach's alpha, the factors of conscience, agreeableness, and neuroticism show negative values, despite checking the coding, which directly affects the instrument's reliability. 
Table 1: Factor Structure of BFI-S in Panama

\begin{tabular}{|c|c|c|c|c|c|c|}
\hline Factor & $\begin{array}{l}\text { Item } \\
\text { No. }\end{array}$ & Reactive & rit & Charge & $\begin{array}{l}\text { Explained } \\
\text { variance }\end{array}$ & Alpha \\
\hline \multirow[t]{3}{*}{1 Opening } & 7 & $\begin{array}{l}\mathrm{He} \text { is original, and he comes } \\
\text { up with new ideas }\end{array}$ & .428 & .730 & 16.256 & .663 \\
\hline & 8 & $\begin{array}{l}\text { Values the artistic, the } \\
\text { aesthetic }\end{array}$ & .419 & .594 & & \\
\hline & 9 & Has a very active imagination & .400 & .739 & & \\
\hline \multirow{3}{*}{$\begin{array}{l}2 \\
\text { Extraversion }\end{array}$} & 4 & He likes to talk & .318 & .762 & 11.974 & .059 \\
\hline & 5 & Is outgoing and sociable & .257 & .775 & & \\
\hline & 6 & It is reserved & .028 & -.678 & & \\
\hline \multirow[t]{3}{*}{3 Conscience } & 13 & $\begin{array}{l}\text { You are meticulous about your } \\
\text { work }\end{array}$ & .388 & .489 & 11.492 & $-.327 *$ \\
\hline & 14 & Tends to be lazy, lazy & -.095 & -.753 & & \\
\hline & 15 & Does things efficiently & .346 & .527 & & \\
\hline \multirow{3}{*}{$\begin{array}{l}4 \\
\text { Friendliness }\end{array}$} & 10 & He is sometimes rude to others & -.058 & -.326 & 10.893 & $-.103 *$ \\
\hline & 11 & $\begin{array}{l}\text { He is forgiving; it is not } \\
\text { difficult for him to forgive }\end{array}$ & .249 & .777 & & \\
\hline & 12 & $\begin{array}{l}\text { Is considerate and kind to } \\
\text { almost everyone }\end{array}$ & .381 & .645 & & \\
\hline \multirow{3}{*}{$\begin{array}{l}5 \\
\text { Neuroticism }\end{array}$} & 1 & Cares a lot about things & .259 & .766 & 10.042 & $-.031 *$ \\
\hline & 2 & Gets nervous / often & -.021 & .733 & & \\
\hline & 3 & $\begin{array}{l}\text { Remains calm in difficult } \\
\text { situations }\end{array}$ & .214 & -.383 & & \\
\hline
\end{tabular}

* The value is negative due to a negative average covariance between items. This violates the assumptions of the reliability model. Check item encodings.

\section{Discussion and Conclusion}

The cultural and linguistic richness and social background of Latin America are essential variables that need to be considered when translating and using scales developed by other countries, although efforts have been made to ensure the fidelity of translation and adaptation. This is the case with BFI-S, which has not reached Colombia (Salgado, Vargas-Trujillo, Schmutzler \& Wills-Herrera, 2016), Peru (Domínguez-Lara \& MerinoSotto, 2018) and now Panama. Therefore, the scale does not measure personality traits. It represents an opportunity to research, analyze, and rethink personality theory and the structure to be measured.

Due to the pandemic, the BFI-S and eight other scales were simultaneously contained in a battery. The people in the sample were told to forget the COVID-19 crisis and respond; it is challenging to show neutrality in this case.

It should also be remembered that Crede and collaborators (2012) have expressed the risk of applying the short version of the personality quality scale because of the increased error rates for Type I and Type II and how to overestimate the structure. Pretending to use three elements to evaluate the personality field may seem attractive due to the ease of response and time of application, but, at least in this part of the world, the result is far from favorable. 


\section{Funding}

The Sistema Nacional de Investigación (SNI) and the Grant APY19-009, SENACYT, Panamá, and the Grant MINBUZA-2020.926889 from the Department of European Integration, The Kingdom of the Netherlands supports research activities by Ericka Matus and Jay Molino.

\section{Conflict of Interests}

The authors declare that there is no conflict of interest. Funders have no role in research design, collecting, analyzing, interpreting data, writing manuscripts, or deciding to publish results.

\section{Acknowledgments}

We are grateful to Carmen Fernández, Ana María Florez, Christian Tejeira, Aelén López, Hilda Avilés, Ibeth Vergara, Jéssica Chung, Ricardo Turner, Cristóbal Nieto, Nuria Araguás, Melba Stanziola, Librada Guillero, and Virginia Castillero for posting surveys on their network coverage More participants at the national level.

\section{References}

Brandt, N. D., Becker, M., Tetzner, J., Brunner, M., Kuhl, P., \& Maaz, K. (2020). Personality across the lifespan: Exploring measurement invariance of a Short Big Five Inventory from ages 11 to 84. European Journal of Psychological Assessment, 36(1), 162-173. https://doi.org/10.1027/10155759/a000490 (Supplemental)

Crede' M, Harms P, Niehorster S, \& Gaye-Valentine A. (2012). An evaluation of the consequences of using short measures of the Big Five personality traits. Journal of Personality and Social Psychology 102 (4), 874-888; DOI: 10.1037/a0027403. https://doi.org/10.1037/a0027403PMID: 22352328

Das, A., \& Arora, D. (2020). Positive psychology of resilience: How the big five personality factors mediate resilience. Indian Journal of Positive Psychology, 11(1), 55-58.

DeYoung, C. G., Carey, B. E., Krueger, R. F., \& Ross, S. R. (2016). Ten aspects of the Big Five in the Personality Inventory for DSM-5. Personality Disorders, 7(2), 113-123. https://doi.org/10.1037/per0000170

Dominguez-Lara, S., \& Merino-Soto, C. (2018). Dos versiones breves del Big Five Inventory en universitarios peruanos: BFI-15p y BFI-10p. Liberabit, 24(1), 81-96. https://doi.org/10.24265/liberabit.2018.v24n1.06

Domínguez-Lara, S., Merino-Soto, C., Zamudio, B., \& Guevara-Cordero, C. (2018). Big Five Inventory en Universitarios Peruanos: Resultados Preliminares de su Validación. Psykhe, 27(2), 1-12. https://doi.org/10.7764/psykhe.27.2.1052

Halama, P., Kohút, M., Soto, C. J., \& John, O. P. (2020). Slovak Adaptation of the Big Five Inventory (BFI2): Psychometric Properties and Initial Validation. Studia Psychologica, 62(1), 74-87. https://doi.org/10.31577/sp.2020.01.792

John, O. P., Donahue, E. M. \& Kentle, R. L. (1991). The Big Five Inventory - Versions 4a and 54. Berkeley, CA: University of California, Berkeley, Institute of Personality and Social Research.

John, O. P., Naumann, L. P. \& Soto, C. J. (2008). Paradigm shift to the integrative Big Five trait taxonomy: History, measurement, and conceptual issues. In John OP, Robins, RW, Pervin. LA (Eds.), Handbook of personality: Theory and Research (pp. $114-158)$. New York, NY, US: Guilford Press

Lang, F.R., John, D., Lu"dtke, O., Schupp, J., \& Wagner, G.B. (2011). Short Assessment of the Big Five: Robust Across Survey Methods Except Telephone Interviewing. Behavior Research Methods 43, 548-567. Doi: http://dx.doi.org/10.3758/s13428-011-0066-z.

Lang, F.R., Lu“dtke, O., \& Asendorpf, J.B. (2001). Testgüte und psychometrische Ä quivalenz der deutschen Version des Big Five Inventory (BFI) bei jungen, mittelalten und alten Erwachsenen. Diagnostica, 47. 111-121. Doi: http://dx.doi.org/10.1026//0012-1924.47.3.111.

Lieberoth, A., Cepulic, D., Rasmussen, J., Tran, T., Han, H., Lin, S., Tuominen, J. \& Travaglino, G. (2020). COVIDiSTRESS global survey network (2020, March 30). COVIDiSTRESS global survey. DOI 10.17605/OSF.IO/Z39US. Recuperado de osf.io/z39us

Matus, E. \& Matus G. L. (2020). Escala de actitudes hacia el confinamiento por Covid-19. Propiedades psicométricas. DOI: 10.5281/zenodo.3840712. Repositorio COVID-19. ZENODO.ORG. 
https://nam11.safelinks.protection.outlook.com/?url=https\%3A\%2F\%2Fzenodo.org\%2Frecord\%2F3 840712\%23.XsiVx2hKjb0\&data=02\%7C01\%7C\%7C8199dc37acf840a78a7b08d7fec834a1\%7C84d f9e7fe9f640afb435aaaaaaaaaaa\%7C1\%7C0\%7C637258008134421474\&sdata=BfeWHuhexlCVRv wtrf5KRQpGKxpmsUkRfyi9Gs7TjF0\%3D\&reserved=0

Matus, E., Matus, L., Florez, A., Tejeira, Ch., López, A., Araguas, N., \& Stanziola, M. (julio 18 de 2020). Propiedades psicométricas de la escala PSS10-UCLA de estrés percibido por COVID-19 en Panamá. DOI:10.5281/zenodo.3951184. Repositorio COVID-19. ZENODO.ORG. Recuperado de https://zenodo.org/record/3951184\#.XxOUN3vitPZ

Matus, E., Matus, L., Florez, A., Stanziola, M., Araguás, N., López, A., \& Guerra, L. (2020). Estrés en panamá por COVID-19. Repositorio COVID-19. ZENODO.ORG. DOI:10.5281/zenodo.3966262 Recuperado de https://eur04.safelinks.protection.outlook.com/?url=https\%3A\%2F\%2Fzenodo.org\%2Frecord\%2F39 $66262 \% 23 . \mathrm{XyG}-$ aJ5Kjb0\&data=02\%7C01\%7C\%7Ca1d2320912d24e59cbaa08d833edc2e4\%7C84df9e7fe9f640afb43 5аaаaаaаaаaа\% 7C1\%7C0\% 7C637316443554449947\&sdata=HKj4tLZ7HKwwXvRtM\%2FTU5Xv FbHo\%2BW1UXP1gQpgpIn60\%3D\&reserved=0

Matus, E., Matus, L., Florez, A., Stanziola, M., Araguás, N., López, A., \& Guerra, L. (2020). Estrés en panamá por COVID-19. Revista Cubana de Alternativas en Psicología, 8 (24), 120-135. Recuperado de http://www.alfepsi.org/revista-alternativas-cubanas-en-psicologia-vol8-n24/?fbclid=IwAR1-UgseGUSfCBzxdSvV7V0cnZAtNxQP5SiNja2LM7f5oRGX7y-m2_ccAE

Mezquita, L., Bravo, A. J., Morizot, J., Pilatti, A., Pearson, M. R., Ibáñez, M. I., Ortet, G., \& Cross-Cultural Addictions Study Team. (2019). Cross-cultural examination of the Big Five Personality Trait Short Questionnaire: Measurement invariance testing and associations with mental health. PLoS ONE, 14(12), 1-23. https://doi.org/10.1371/journal.pone.0226223

Salgado, E., Vargas-Trujillo, E., Schmutzler, J., \& Wills-Herrera, E. (2016). Uso del Inventario de los Cinco Grandes en una muestra colombiana. Avances en PsicologÍa Latinoamericana, 34(2), 365-382. https://doi.org/10.12804/apl34.2.2016.10

Schmidt, V., Firpo, L., Vion, D., De Costa, M., Casella, L., Cuenya, L., Blum, G., \& Pedrón, V. (2010). Modelo Psicobiológico de Personalidad de Eysenck: una historia proyectada hacia el futuro. Revista Internacional de Psicología. 11(2), 1-21. Recuperado de https://www.revistapsicologia.org/index.php/revista/article/viewFile/63/60

Soto, C. J., \& John, O. P. (2017). The next Big Five Inventory (BFI-2): Developing and assessing a hierarchical model with 15 facets to enhance bandwidth, fidelity, and predictive power. Journal of Personality and Social Psychology, 113 (1), 117-143. https://doi.org/10.1037/pspp0000096

Soto C. J, \& John O. P. (2017). Short and extra-short forms of the Big Five Inventory-2: the BFI-2-S and BFI-2-XS. Journal of Research in Personality, 68, 69-81. https://doi.org/10.1016/j.jrp.2017.02.004

Stricker, J., Buecker, S., Schneider, M., Preckel, F., \& Kandler, C. (2019). Multidimensional Perfectionism and the Big Five Personality Traits: A Meta-analysis. European Journal of Personality, 33(2), 176196. https://doi.org/10.1002/per.2186

Sutin, A. R., Luchetti, M., Aschwanden, D., Lee, J. H., Sesker, A. A., Strickhouser, J. E., Stephan, Y., \& Terracciano, A. (2020). Change in five-factor model personality traits during the acute phase of the coronavirus pandemic. PLoS ONE, 14(8), 1-13. https://doi.org/10.1371/journal.pone.0237056

Zhang, X., Wang, M.-C., He, L., Jie, L., \& Deng, J. (2019). The development and psychometric evaluation of the Chinese Big Five Personality Inventory-15. PLoS ONE, 14(8), 1-21.

https://doi.org/10.1371/journal.pone.0221621 